\title{
To study second trimester placental location as a predictor of adverse pregnancy outcome
}

\author{
Neetu Singh*, Renu Gupta, Kiran Pandey, Neena Gupta, Ani Chandanan, Priya Singh
}

Department of Obstetrics and Gynecology, GSVM Medical College, Kanpur, India

Received: 08 February 2016

Revised: 09 April 2016

Accepted: 12 April 2016

\author{
*Correspondence: \\ Dr. Neetu Singh, \\ E-mail: priyakg05@gmail.com
}

Copyright: () the author(s), publisher and licensee Medip Academy. This is an open-access article distributed under the terms of the Creative Commons Attribution Non-Commercial License, which permits unrestricted non-commercial use, distribution, and reproduction in any medium, provided the original work is properly cited.

\begin{abstract}
Background: Pregnancy and childbirth is universally celebrated as an event. It can also be one of experiences of misery and suffering when complications or adverse circumstances comprise the pregnancy, causing morbidity or even mortality. To study second trimester placental localization as a predictor of adverse pregnancy outcome.

Methods: The study was conducted in Upper India Sugar Exchange Maternity Hospital, GSVM Medical College, Kanpur, India from January 2014 to July 2015 on 592 pregnant women between 18-24 week over a period of 16 months.

Results: This study shows that lateral placental location was associated with increased incidence of preeclampsia, intrauterine growth restriction and posterior placental location associated with preterm labour and stillbirth.

Conclusions: Placental localization by ultrasound in pregnant women during 18-24 week of gestation can be used as easy, non-invasive, cost-effective tool as a predictor of adverse pregnancy outcome.
\end{abstract}

Keywords: Placenta, Preeclampsia, Preterm, IUGR, Still birth

\section{INTRODUCTION}

Pregnancy and childbirth is universally celebrated as an event. It can also be one of experiences of misery and suffering when complications or adverse circumstances comprise the pregnancy, causing morbidity or even mortality. Placenta is an important connecting organ between mother and fetus, a lot of fetus problems related with placenta. It is the vital link between the mother and the fetus for metabolic exchange, endocrine and other body functions, is critical for maternal, neonatal wellbeing. The blood supply of placenta is not uniformly distributed. As such, the size of implantation and resultant location of the placenta within the uterus are likely important determinants of placental blood flow and therefore pregnancy success. Placental location has been implicated in preterm birth, in fetal mal-position and malpresentation, small for gestational age, low Apgar score and in development of pre-eclampsia. ${ }^{1-4}$ The significance of placental location in the uterine cavity has been studied extensively. Placental location has been found to correlate with fetal position and presentation, length of gestation, course of labour, presence of pre-eclampsia. Several methods have been used to document placental location, including manual exploration of uterus, soft tissue $x$-ray films, isotopic placentography. In the past two decades, ultrasound has proved to be the safest, easiest and most accurate method for assessing placental location. USG of placenta is primarily directed toward determining the location of the placenta and identifying its abnormalities in the later weeks of pregnancy. However, the advent of high-resolution transvaginal ultrasound (TVS) has revolutionized the understanding of placental studies, and it is believed that placental evaluation in early pregnancy could be useful in identifying the risks for subsequent disorders. The site of implantation that decides the location of placenta is likely to be important determinant of placental blood flow and therefore pregnancy outcome.

Ultrasound imaging has become an integral component of routine prenatal medical care for most pregnant women. 
During an obstetrical ultrasound, evaluation of the fetus is chief priority but often, the other components (placenta, umbilical cord, and amniotic fluid) which represent an integral part of gestation, are arguably not given the attention they deserve.

Preeclampsia occurs only in the presence of placenta. ${ }^{5}$ The poorly perfused placenta may be the origin of factors which gain access to maternal vasculature and cause endothelial cell dysfunction. Reduced placental perfusion in preeclampsia is thought to result from failure of the trophoblasts to invade maternal spiral artery. ${ }^{6}$ Among the various predictors for preeclampsia, the placental location by ultrasound at $18-24$ weeks is very cost effective, noninvasive, and has a good positive predictive value. There is a significant association between placental location and uterine artery resistance and adverse outcomes such as preeclampsia and IUGR.

It has been shown that in humans, both uterine arteries have a significant number of branches and that each supply the corresponding side of the uterus. Although anastomoses between the two uterine arteries exist, there is no proof that these are functional. When the placenta is laterally located, the uterine artery closer to the placenta has lower resistance than one opposite it. In patients with centrally located placentas both uterine arteries demonstrated similar resistance. When the placenta is centrally located, the uteroplacental blood flow needs are met with by equal distribution from both uterine arteries. However, when placenta is laterally located, in the majority of cases the uteroplacental blood flow needs are met with primarily by one of the uterine arteries with some contribution from the other uterine artery via collateral circulation. The degree of collateral circulation may not be the same in all subjects and deficient contribution may facilitate the development of preeclampsia, intrauterine growth retardation or both. The significance of normal placentation for this cytotrophoblasitc invasion is high and the cytotrophoblasts fail to adopt a vascular adhesion phenotype in preeclampsia. Quantitative analysis of trophoblast invasion in preeclampsia had shown restricted invasion of trophoblastic cells in preeclampsia. ${ }^{7}$ This may explain the reduced trophoblastic invasion in laterally situated placenta when the uteroplacental blood flow needs are mainly met with by that side uterine artery.

There is a significant association of posterior placenta and preterm labour and stillbirth. ${ }^{8}$ This is probably because placenta located on the posterior uterine wall may be somehow less efficient due to the anatomy of that wall. As a result of uneven uterine blood supply, the posterior wall of the pregnant uterus is longer and somewhat thicker. Each of these factors may affect uterine blood supply, especially as the uterus expands to accommodate the pregnancy.

In the light of these observations, we designed a prospective study to find out whether the location of placenta as seen by ultrasound at 18-24 weeks of gestation can be used to prediction of adverse pregnancy outcome. Result of this study may provide insight as second trimester placental localization by USG can be used as effective screening modalility for various pregnancy related complication and its outcome.

\section{METHODS}

The study was conducted in Upper India Sugar Exchange Maternity Hospital, GSVM Medical College , Kanpur from January 2014 to July 2015 on 592 pregnant women between 18-24 week over a period of 16 months. The study was prospective observational study. The cases were randomly allocated. The subjects of study were pregnant women attending antenatal clinics.

\section{Inclusion criteria}

All pregnant women with singleton pregnancy between 18 to 24 th week of gestation. Gestation age of the patient was calculated from the first day of the last menstrual period (LMP) and if it was not known, then by available ultrasonographic parameters preferably in first trimester by crown rump length (CRL) and in second trimester by bi-parietal diameter and femoral length etc.

Overall 688 patients were enrolled in the study, 80 were lost in follow up, 16 had $2^{\text {nd }}$ trimester abortion .So 592 pregnant women included in our study. They were regularly followed till the outcome of pregnancy. All pregnant female get their ultrasound between $18-24^{\text {th }}$ week of pregnancy. Apart from clinical evaluation or by detailed history, physical and gynaecological examination also done.

When placenta was equally distributed between the right and left side of uterus it was classified as anterior, posterior, or fundal position and collectively this group termed as central placenta. When $75 \%$ or more of the placental mass was to one side of the midline, it was classified as unilateral right or left placenta.

Follow up USG performed at 36 week, earlier if indicated and performed colour Doppler if required.

All pregnant female were followed till delivery and maternal outcome was noted in the form of complication and mode of delivery, fetal outcome was reported in term of:

- $\quad$ Live birth

- $\quad$ Still birth

- Neonatal death

- Weight of baby

- APGAR Score 


\section{RESULTS}

Table 1 shows age group of patients we studied. Maximum number of pregnant females in our study belongs to 20-25 year and 25-30 year age group with $39.5 \%$ and $31.5 \%$.
Table 1: Age wise distribution.

\begin{tabular}{|lll|}
\hline Age in years & Number $(\mathbf{n = 5 9 2})$ & $\%$ \\
\hline$<20$ Yrs & 112 & 19.9 \\
\hline $20-25$ yrs & 233 & 39.5 \\
\hline $25-30$ yrs & 209 & 31.4 \\
\hline$>30 y r s$ & 39 & 9.2 \\
\hline
\end{tabular}

Table 2: Relationship between placental location and maternal outcome.

\begin{tabular}{|c|c|c|c|c|c|c|c|c|c|c|}
\hline \multirow[t]{2}{*}{$\begin{array}{l}\text { Placental } \\
\text { location }\end{array}$} & \multirow[b]{2}{*}{ No } & \multirow{2}{*}{$\begin{array}{l}\text { Normal } \\
(n=344) \\
\%\end{array}$} & \multirow[b]{2}{*}{ No } & \multirow{2}{*}{$\begin{array}{l}\text { Preeclampsia } \\
(\mathrm{n}=124) \\
\%\end{array}$} & \multirow[b]{2}{*}{ No } & \multicolumn{2}{|c|}{$\begin{array}{l}\text { IUGR } \\
(\mathrm{n}=53)\end{array}$} & \multicolumn{2}{|c|}{$\begin{array}{l}\text { Preterm } \\
\text { birth }(n=65)\end{array}$} & \multirow{2}{*}{$\begin{array}{l}\text { Stillbirth } \\
(n=6) \\
\%\end{array}$} \\
\hline & & & & & & $\%$ & No & $\%$ & No & \\
\hline Anterior $(n=111)$ & 74 & 21.77 & 16 & 12.9 & 5 & 9.4 & 15 & 23.07 & 1 & 25 \\
\hline Posterior $(\mathrm{n}=86)$ & 36 & 10.7 & 12 & 9.6 & 5 & 9.4 & 30 & 46.15 & 3 & 50 \\
\hline Fundal $(n=169)$ & 129 & 36.80 & 18 & 14.51 & 10 & 15.3 & 10 & 15.38 & 1 & 25 \\
\hline Lateral $(n=226)$ & 105 & 30.67 & 78 & 62.9 & 33 & 62.26 & 10 & 15.38 & 0 & 0 \\
\hline
\end{tabular}

Table 3: Neonatal outcome.

\begin{tabular}{|c|c|c|c|c|}
\hline \multicolumn{3}{|c|}{ Outcome in neonate } & Number & $\%$ \\
\hline \multirow{2}{*}{$\begin{array}{l}\text { Birth } \\
\text { weight }\end{array}$} & \multicolumn{2}{|l|}{$<2.5 \mathrm{~kg}$} & 285 & 48.1 \\
\hline & \multicolumn{2}{|l|}{$>2.5 \mathrm{~kg}$} & 327 & 51.9 \\
\hline \multirow{4}{*}{$\begin{array}{l}\text { Apgar } \\
\text { score }\end{array}$} & In $1 \mathrm{~min}$ & $<7$ & 56 & 9.4 \\
\hline & & $>7$ & 536 & 90.54 \\
\hline & $5 \mathrm{~min}$ & $<7$ & 53 & 8.9 \\
\hline & & $>7$ & 539 & 91.1 \\
\hline \multicolumn{3}{|c|}{ Neonatal admission } & 96 & 16 \\
\hline \multicolumn{3}{|c|}{ Neonatal mortality } & 12 & 2.02 \\
\hline
\end{tabular}

Relation of placental location with pregnancy outcome is shown in Table 2. In our study we found that in pregnant female in whom placenta was laterally located, there was increased risk of development of preeclampsia with $\mathrm{p}$ value highly significant, 2.578 (odds ratio) with $95 \%$ CI (1.694-3.924). In 124 preeclampsia patients, $78(62.9 \%)$ had laterally located placenta so placental laterality can be simple and reliable predictor of preeclampsia. In pregnant female who had laterally located placenta, chances of IUGR were also significantly increased with $p$ value < .0018 and 3.006 (odds ratio) with $95 \%$ CI (1.678-5.385). In 53 female who was having IUGR, 33 $(62.26 \%)$ had lateral placenta so there is positive correlation between IUGR and lateral placenta. In posterior located placenta, there were increased risk of preterm labour and stillbirth. Out of 94 posterior placenta, $30(31.9 \%)$ female land up into preterm labour. Association is statistically significant $(\mathrm{p}<0.0001)$. Out of 592 patients who were included in our study, $8(1 \%)$ patients had stillbirth and in that group of patients 4 $(50 \%)$ were having posteriorly located placenta .p value is statistically significant $<0.0188$.

Table 3 shows that $48.1 \%$ neonate having birth weight $<2.5 \mathrm{~kg}$ and $51.9 \%$ had birth weight $>2.5 \mathrm{~kg}$. $9.4 \%$ neonate had Apgar score at $1 \mathrm{~min}$. with score $<7$ and
$90.6 \%$ had score $>7.96(16.21 \%)$ required neonatal intensive care admission and $12(1.2 \%)$ were expired. In our study maximum number of neonate who were admitted in NICU belong to high risk group (Preeclampsia, IUGR, Preterm) so from this study of we carefully monitored their antenatal complication.

\section{DISCUSSION}

The significance of placental location in the uterine cavity has been studied extensively. In the past two decades, ultrasound has proved to be the safest, easiest and most accurate method for assessing placental location. Multiple studies have done to establish association of placental location and adverse pregnancy outcome like preeclampsia, IUGR, preterm and stillbirth. There is a significant association between placental location and uterine artery resistance. High uterine artery resistance leads to decreased uterine artery blood flow and adverse pregnancy outcomes.

In this study it was seen that laterally located placenta on ultrasound done at 18-24 weeks was associated with increased risk of development of preeclampsia and IUGR. Females with laterally located placenta found to have a 2 times greater risk of preeclampsia. This result is in accordance with Kofinas et al who concluded that in women with unilateral placenta, the incidence of preeclampsia was 2.8-fold greater than those with centrally located placenta. Similar to our study Anuja V Bhalero et al reported that out of 300 women, $168(56 \%)$ females had laterally located placenta and 132 (44\%) had centrally located placenta. ${ }^{9,10}$ Out of the 168 women with laterally located placenta, $112(66.6 \%)$ developed PIH as compared to 132 females with centrally located placenta where $48(36.6 \%)$ developed PIH. So, the risk of developing $\mathrm{PIH}$ was five times greater for the females with laterally located placenta as compared to those with 
centrally located placenta. The result of present study were also comparable to study done by Gonser et al that lateral implantation increases the risk of preeclampsia. ${ }^{11}$ In our study out of 94 posterior placentas, 30 (31.9\%) female land up into preterm labour so posterior located placenta can be taken as indicator of preterm labour. Association is statistically significant $(\mathrm{p}<0.0001)$. Our finding consistent with another study done by Shulman et al that shows significant association of posterior placenta and preterm labour. ${ }^{8}$ Similar results are found in study by Hadley et al. ${ }^{1}$ In our study, the association between lateral location of placenta with IUGR was statistically significant ( $p$ value $<0.0018$ ). This result is accordance with Kalaniti et al who studied that in IUGR babies chances to find lateral placenta are more than 3.8 times than normal babies. ${ }^{2}$ In present study, association of posteriorly located placenta with still birth found to be significant ( $\mathrm{p}$ value $<0.0001$ ). The result of present study were comparable to study done by Jane Warland et al, the result of which showed that posterior placenta may be more prevalent in stillbirth than when the baby is live born. ${ }^{13}$

Our study is an effort to establish the association of placental location with different maternal and neonatal outcome so that it can help us to determine various maternal and fetal complications in form of preeclampsia, preterm labour, IUGR and stillbirth etc. So placental locations in second trimester can be used as a predictor to screen out high risk pregnant females which will help in prevention of adverse pregnancy outcome.

\section{CONCLUSION}

In this study, we concluded that USG in pregnant women during 18-24 week of gestation can be used as easy, noninvasive, cost-effective tool as a predictor of adverse pregnancy outcome. Our results are in accordance with many studies done before.

Funding: No funding sources Conflict of interest: None declared

Ethical approval: The study was approved by the Institutional Ethics Committee

\section{REFERENCES}

1. Hadley CB, Main DM, Gabbe SG. Risk factors for premature rupture of the fetal membranes. Am J Perinatol. 1990;7:374-9.

2. Kalanithi LE, Illuzzi JL, Nossov VB, Frisbaek Y, Abdel-Razeq S, Copel JA, et al. Intrauterine growth restriction and placental location. J Ultrasound Med. 2007;26:1481-9.

3. Hoogland HJ, de Haan J. Ultrasonographic placental localization with respect to fetal position in utero. Eur JObstetGynecolReprodBiol. 1980;11:9-15.

4. Magann EF, Doherty DA, Turner K, Lanneau GS, Jr, Morrison JC, Newnham JP. Second trimester placental location as a predictor of an adverse pregnancy outcome. JPerinatol. 2007;27:914.

5. Walker JJ. Current thoughts on the pathophysiology of preeclampsia/eclampsia. 1998.

6. Fleischer A, Schulman H, Farmakides G, et al. Uterine artery Doppler velocimetry in pregnant women with hypertension. AM. J Obstet Gynaecol. 1986;154:806-13.

7. Khong TY, De Wolf F, Robertson WB, Brosens I. Inadequate maternal vascular response to placentation in pregnancies complicated by preeclampsia and by small-for-gestational age infants. Br J Obstet Gynaecol. 1986;93:1049-59.

8. Schulman H, Winter D, Farmakides $G$ et al. Pregnancy surveillance with Doppler velocimetry of uterine and umbilical arteries. AM J Obstet Gynaecol. 1989;160:192-6.

9. Kofinas AD, Penry M, Swain M, Hatjis CG. Effect of placental laterality on uterine artery resistance anddevelopment of preeclampsia and intrauterine growth retardation. AM.J Obstet Gynecol. 1989;161:153-69.

10. Bhalerao AV, Kulkarni S, Somalwa S. Lateral placentation by USG: A simple predictor of PET: J South Asian Obs Gynae. 2013;5(2):68-71.

11. Gonser M, Tillack N, Pfeiffer KH, Mielke G. Placental location and incidence of preeclampsia. Ultraschall Med. 1996;17:236-8.

12. Warland J, McCutcheon H, Baghurst P. Placental position and late stillbirth : a case control study. J Clin Nurs. 2009;18(11):1602-6.

Cite this article as: Singh N, Gupta R, Pandey K, Gupta N, Chandanan A, Singh P. To study second trimester placental location as a predictor of adverse pregnancy outcome. Int J Reprod Contracept Obstet Gynecol 2016;5:1414-7. 